\title{
Regenerative Cell Therapy After Myocardial Infarction: Cells or Growth Factors?
}

\author{
Felipe Prósper
}

Servicio de Hematología y Área de Terapia Celular, Clínica Universitaria, Universidad de Navarra, Pamplona, Navarra, Spain.

With the exception of hematopoietic cell transplantation in patients with hematological and oncological disease, heart disease, specifically myocardial infarction, features as the next most important indication for stem cell therapy. A little more than 3 years ago, Philippe Menasche was the first to describe the use of stem cells to treat a patient who had presented myocardial infarction. ${ }^{1}$ He justified this indication in more than a dozen studies carried out over more than 10 years with experimental models of myocardial infarction, demonstrating the potential benefit to cardiac function of skeletal myoblast transplantation and, thus, supported the step to experimenting on human subjects. ${ }^{2}$ In the case of other types of stem cells, such as bone marrow cells or endothelial cells, things have developed more rapidly; in barely 3 years we have gone from experimental studies hinting at the possibility of regenerating the heart with bone marrow stem cells, ${ }^{3}$ which, on the other hand, were strongly criticized,,${ }^{4,5}$ to random clinical trials. ${ }^{6}$ Unfortunately, despite all the many experimental and clinical trials done during the last few years, we still do not have answers to many of the questions needed to establish cell therapy as an effective treatment from the clinical point of view. Obviously, until we know in detail the mechanisms involved in improving cardiac function, we cannot properly decide which cells are the most appropriate, what are the indications for cell therapy, what is the required dose of cells or even whether it is necessary to transplant cells.

The other side of the coin is the patients' point of view and, to a lesser extent, the opinion of the clini-

Correspondence: Dr. F. Prósper.

Servicio de Hematología y Área de Terapia Celular. Clínica Universitaria de Navarra.

Avda. Pío XII, 36. 31008 Pamplona. Navarra. España. cians who treat such patients: while safeguarding the fundamental Hippocratic principle of not causing harm, should we wait for answers to all of these questions before applying these therapeutic strategies in our patients? Recently, Nature published an editorial prompted by the publication of the 2 studies we have referred to, which rejected the capacity of bone marrow stem cells to contribute to cardiac regeneration. ${ }^{4,5}$ It justified delaying clinical trials until it was possible to respond to a series of principles described in the form of ten precepts. ${ }^{7}$ There is no doubt that, if we follow these criteria, many of the efforts currently under way would have to be interrupted thus entailing, at least in my opinion, serious harm to our patients. Therefore, we should aim at striking a certain balance to enable steady advances both in fundamental research and the clinical aspects of cell therapy.

The article published in this issue of REvisTA EsPAÑOLA DE CARDIOLOGIA, ${ }^{8}$ although having the limitations common to a phase I study with a small number of patients, offers an especially attractive hypothesis within the clinical context: if there are stem cells in the adult body capable of helping to regenerate cardiac function, then instead of searching for them, isolating them, cultivating them in vitro, and then administering them to the patients, with all the consequent economic costs and technical difficulties involved, we could try to stimulate these stem cells in such a way that they could arrive at the site where they are needed without even having to extract them from the body. The idea is simple and attractive. In addition to the authors' argument, evidence from experimental models supports this hypothesis. Piero Anversa's group has been pioneering this line of work, and has demonstrated in murine myocardial infarction models that it is possible to mobilize stem cells located in adult organs, probably in the bone marrow, and that these cells contribute to repairing damaged myocardium. ${ }^{9}$ However, it is important to emphasize that in these studies the mobilization of cytokines begins before the infarction occurs, which is a very different situation to that found in patients with myocardial infarction. Studies carried out 
in primates have not been able to reproduce the good results obtained with mice. ${ }^{10}$

Suárez de Lezo's study was one of the first works published that used this therapeutic strategy in patients with myocardial infarction and it raises interesting issues that deserve consideration. ${ }^{11,12}$ Obviously, adverse effects and the patient's safety are the fundamental issues in any phase I study such as the one presented by the Córdoba group. In general, there has been a low incidence of adverse events in the various clinical trials published to date on cardiac regeneration. The transplantation of skeletal myoblasts in patients with chronic myocardial infarction has been associated with a greater incidence of cardiac arrhythmias ${ }^{13}$ in some studies, although not in all, ${ }^{14}$ whereas the use of hematopoietic stem cells via the intracoronary route has been associated at least in one study with a higher rate of stent restenosis, mainly in patients treated with stem cells together with hematopoietic growth factors (GCSF). ${ }^{11}$ Other works, carried out both by Spanish and non-Spanish groups, have not found this increase in the restenosis rate. ${ }^{15,16}$ Given that this is one of the very first works using G-CSF as a treatment its conclusions regarding complications are particularly relevant. In this regard it is worthwhile pointing out that one of the patients suffered splenic rupture as a serious complication. Although the use of hematopoietic growth factors, mainly G-CSF, is customary practice in hematology and oncology, the incidence of splenic ruptures is very low. ${ }^{17}$ Most hematologists and oncologists will see hundreds of patients treated with G-CSF during their career, but will never see a case of splenic rupture. On the other hand, in Suárez de Lezo's study the incidence was $8 \%$. This could be an isolated event or that the underlying disease and the patients' situation favored the development of this complication. Obviously, myocardial infarction triggers inflammatory events that could contribute to the onset of this type of adverse effect. It could also have a relationship with the length of treatment with the growth factor. The authors used normal doses of growth factor for the mobilization of hemopoietic progenitors in patients and the donors were healthy; however, the treatment was longer than normal since apheresis is usually done to extract progenitor cells on the fifth day of treatment and tends not to last more than 1 week. Taking into account that the splenic rupture occurred on the eighth day of treatment and that the peak of mobilization in this and many other works occurred on the fifth day after treatment, it may not be necessary to prolong treatment with G-CSF

I would like to take advantage of this issue to offer a cautionary note: although not wishing to underestimate the interest of this work and its potential application, we should not get carried away by the fact that treatment with G-CSF in patients with a myocardial infarction is quite simple and, thus, could be used in both large hospitals and smaller centers with smaller infrastructures. In this sense, it is important to give a strong, clear warning against applying this treatment outside the context of clinical trials and studies aimed at establishing the therapeutic safety and efficacy of the mobilizing treatment in patients with myocardial infarction. Any other line of action would be of little benefit to our patients and could jeopardize the future of this type of treatment.

The authors have clearly been very conscientious when assessing the effect of the treatment on cardiac function, but despite their efforts, assessing the efficacy of treatment with G-CSF remains a difficult and unavoidable problem. The actual design of the study aims at assessing the safety of the treatment, but trying to draw conclusions regarding the therapeutic efficacy of the administration of G-CSF in patients with myocardial infarction is risky. Given that the first step has been taken, we now urge the researchers to take the next step. If we want to find out about the true efficacy of the treatment, we have to design and carry out random studies to determine the efficacy of the treatment with hematopoietic growth factors in myocardial infarction patients. An additional issue when assessing the results obtained is the large variability observed regarding the effect on cardiac function of the treatment used (revascularization, stenting and treatment with G-CSF). Whereas in some patients cardiac function deteriorates, in others there is a very significant improvement. This effect leads us to think that there are many variables that might contribute to altering the functional results of the treatment, even more than the treatment itself, such as the magnitude of the myocardial infarction, the revascularization treatment, the time from the myocardial infarction to starting treatment or others that remain unknown. New studies should be designed to create homogeneous groups in order to minimize this variability.

Phenotypic analysis of the mobilized cells enabled the authors to demonstrate that the number of stem and progenitor cells increases in the patients' blood very significantly. This aspect was certainly rigorously and fully dealt with in this study. However, trying to draw conclusions regarding the relationship between the type of mobilized cells and functional improvement is premature. First, we do not know what type of stem cells are capable of contributing to myocardial regeneration and even less what mechanisms they use to contribute to this improvement. Although some studies suggest that hematopoietic cells are capable of regenerating the myocardium, differentiating themselves into cardiac muscle fibers, endothelium, or smooth muscle, ${ }^{3}$ these differentiation events are at least questionable because other groups have not been able to confirm them ${ }^{4,5}$ or because other mechanisms such as cellular fusion are involved in the apparent differentiation. ${ }^{18}$ There is evidence that other types of stem cells, 
such as cells derived from fat or mesenchymal stem cells, are capable of differentiating and giving rise to endothelial and cardiac cells. ${ }^{19,20}$ It is possible that the treatment with G-CSF had an effect on these types of cell, but in any case the phenotype of these cells would be quite different from the phenotype of the hematopoietic cells described in the work of the Córdoba group. Second, the limited number of patients means that any correlation between the phenotype of the mobilized cells and functional improvement is more anecdotal rather than being a correlation with biological meaning.

Despite the study's limitations, I believe Suárez de Lezo's work is of great interest due to its novelty and the conclusions that can be derived from it, mainly related to the safety of the treatment. It opens up new perspectives and places a Spanish group in the competitive world of regenerative cell therapy. I hope this work serves as an encouragement for other Spanish groups and helps to unite efforts toward designing random studies that in the long-run will serve as a basis for the rational clinical application of myocardial regeneration therapy with stem cells. Ultimately, it will help to improve the quality and length of our patients' lives which is our most fundamental aim as physicians.

\section{REFERENCES}

1. Menasche P, Hagege AA, Scorsin M, Pouzet B, Desnos M, Duboc D, et al. Myoblast transplantation for heart failure. Lancet. 2001;357:279-80.

2. Menasche P. Skeletal muscle satellite cell transplantation. Cardiovasc Res. 2003;58:351-7.

3. Orlic D, Kajstura J, Chimenti S, Jakoniuk I, Anderson SM, Li B, et al. Bone marrow cells regenerate infarcted myocardium. Nature. 2001;410:701-5.

4. Balsam LB, Wagers AJ, Christensen JL, Kofidis T, Weissman IL, Robbins RC. Haematopoietic stem cells adopt mature haematopoietic fates in ischaemic myocardium. Nature. 2004;428:668-73.

5. Murry CE, Soonpaa MH, Reinecke H, Nakajima H, Nakajima HO, Rubart M, et al. Haematopoietic stem cells do not transdifferentiate into cardiac myocytes in myocardial infarcts. Nature. 2004;428:664-8

6. Wollert KC, Meyer GP, Lotz J, Ringes-Lichtenberg S, Lippolt P, Breidenbach $\mathrm{C}$, et al. Intracoronary autologous bone-marrow cell transfer after myocardial infarction: the BOOST randomised controlled clinical trial. Lancet. 2004;364:141-8.

7. Chien KR. Stem cells: lost in translation. Nature. 2004;428: 607-8.

8. Suárez de Lezo J, Torres A, Herrera I, Pan M, Romero M, Pavlovic $\mathrm{D}$, et al. Efectos de la movilización de células madre mediante el uso de factor estimulante de colonias granulocíticas en pacientes con infarto agudo de miocardio anterior revascularizado percutáneamente. Rev Esp Cardiol. 2005;58:251-9.

9. Orlic D, Kajstura J, Chimenti S, Limana F, Jakoniuk I, Quaini F, et al. Mobilized bone marrow cells repair the infarcted heart, improving function and survival. Proc Natl Acad Sci USA. 2001;98: 10344-9.

10. Norol F, Merlet P, Isnard R, Sebillon P, Bonnet N, Cailliot C, et al. Influence of mobilized stem cells on myocardial infarct repair in a nonhuman primate model. Blood. 2003;102:4361-8.

11. Kang HJ, Kim HS, Zhang SY, Park KW, Cho HJ, Koo BK, et al. Effects of intracoronary infusion of peripheral blood stem-cells mobilised with granulocyte-colony stimulating factor on left ventricular systolic function and restenosis after coronary stenting in myocardial infarction: the MAGIC cell randomised clinical trial. Lancet. 2004;363:751-6.

12. Kuethe F, Figulla HR, Voth M, Richartz BM, Opfermann T, Sayer HG, et al. Mobilization of stem cells by granulocyte colonystimulating factor for the regeneration of myocardial tissue after myocardial infarction. Dtsch Med Wochenschr. 2004;129:424-8.

13. Menasche P, Hagege AA, Vilquin JT, Desnos M, Abergel E, Pouzet B, et al. Autologous skeletal myoblast transplantation for severe postinfarction left ventricular dysfunction. J Am Coll Cardiol. 2003;41:1078-83.

14. Herreros J, Prosper F, Pérez A, Gavira JJ, García-Velloso MJ, Barba J, et al. Autologous intramyocardial injection of cultured skeletal muscle-derived stem cells in patients with non-acute myocardial infarction. Eur Heart J. 2003;24:2012-20.

15. Fernández-Avilés F, San Román JA, García Frade J, Valdés M, Sánchez A, de la Fuente L, et al. Regeneración miocárdica mediante la implantación intracoronaria de células madre en el infarto agudo de miocardio. Rev Esp Cardiol. 2004;57:201-8.

16. Fernández-Avilés F, San Román JA, García-Frade J, Fernández ME, Penarrubia MJ, De la Fuente L, et al. Experimental and clinical regenerative capability of human bone marrow cells after myocardial infarction. Circ Res. 2004;95:742-8.

17. Balaguer H, Galmes A, Ventayol G, Bargay J, Besalduch J. Splenic rupture after granulocyte-colony-stimulating factor mobilization in a peripheral blood progenitor cell donor. Transfusion. 2004:44:1260-1.

18. Álvarez-Dolado M, Pardal R, García-Verdugo JM, Fike JR, Lee $\mathrm{HO}$, Pfeffer K, et al. Fusion of bone-marrow-derived cells with Purkinje neurons, cardiomyocytes and hepatocytes. Nature. 2003; 425:968-73.

19. Jiang Y, Jahagirdar BN, Reinhardt RL, Schwartz RE, Keene CD, Ortiz-Gonzalez XR, et al. Pluripotency of mesenchymal stem cells derived from adult marrow. Nature. 2002;418:41-9.

20. Planat-Benard V, Menard C, Andre M, Puceat M, Pérez A, García-Verdugo JM, et al. Spontaneous cardiomyocyte differentiation from adipose tissue stroma cells. Circ Res. 2004;94:223-9. 